ISSN 1814-6023 (Print)

ISSN 2524-2350 (Online)

UDC 617.51/.52:616.2]-073.756.8

https://doi.org/10.29235/1814-6023-2020-17-3-346-352

Received 08.04.2020

\author{
Sergey P. Rubnikovich ${ }^{1}$, Irina S. Abelskaya ${ }^{1}$, Yuliya L. Denisova ${ }^{2}$, \\ Sergey V. Sirak ${ }^{3}$, Vladimir G. Shishov ${ }^{1}$
}

${ }^{1}$ Belarusian Medical Academy of Postgraduate Education, Minsk, Republic of Belarus

${ }^{2}$ Belarusian State Medical University, Minsk, Republic of Belarus

${ }^{3}$ Stavropol State Medical University, Stavropol, Russian Federation

\title{
PROSPECTS OF APPLICATION OF CONE BEAM COMPUTED TOMOGRAPHY FOR ANALYZING UPPER RESPIRATORY TRACT PATHOLOGIES IN PATIENTS WITH DENTITION SYSTEM DISEASES
}

\begin{abstract}
The goal of the study was to analyze the upper respiratory tract condition indicators obtained by means of cone beam computed tomography (CBCT) for patients with dentition system diseases and obstructive sleep apnoea syndrome.

Patients were divided into 3 study groups. The control group (the 1st study group) included the CBCT data obtained for 33 healthy patients. The 2nd study group included the CBCT data obtained for 136 patients with dentition system diseases (partial secondary edentia combined with chronic generalized periodontitis) without sleep disorder signs. The 3rd study group included the CBCT data obtained for 70 patients with partial secondary edentia combined with deep distal occlusion and obstructive sleep apnoea syndrome (OSAS).

The CBCT method using the proposed diagnosis criteria made it possible to identify not only dentition system diseases, but also the dysfunction of the upper respiratory tract, in particular the OSAS causes. It was found with confidence that the reduction of the upper respiratory tract diagnostic indicators by $40 \%$ or more, as compared to the regulatory indicators of healthy patients, led to the dysfunction of the respiratory tract and the apnoea development. Deep distal occlusion and secondary edentia conditioned the presence of the upper respiratory tract concave configuration and the localization of the minimum cross-sectional area below the occlusion plane, which increases the probability of development and progression of the obstructive sleep apnoea syndrome.

Keywords: sleep apnoea, cone beam computed tomography, periodontitis, edentia, upper respiratory tract

For citation: Rubnikovich S. P., Abelskaya I. S., Denisova Yu. L., Sirak S. V., Shishov V. G. Prospects of application of cone beam computed tomography for analyzing upper respiratory tract pathologies in patients with dentition system diseases. Vestsi Natsyyanal'nai akademii navuk Belarusi. Seriya meditsinskikh navuk = Proceedings of the National Academy of Sciences of Belarus. Medical series, 2020, vol. 17, no. 3, pp. 346-352. https://doi.org/10.29235/1814-6023-2020-17-3-346-352
\end{abstract}

\section{С. П. Рубникович ${ }^{1}$, И. С. Абельская ${ }^{1}$ Ю. Л. Денисова ${ }^{2}$ С. В. Сирак ${ }^{3}$ В. Г. Шишов}

${ }^{\prime}$ Белорусская медицинская академия последипломного образования, Минск, Республика Беларусь

${ }^{2}$ Белорусский государственный медииинский университет, Минск, Республика Беларусь

${ }^{3}$ Ставропольский государственный медицинский университет, Ставрополь, Российская Федерация

\section{ПЕРСПЕКТИВЫ ПРИМЕНЕНИЯ КОНУСНО-ЛУЧЕВОЙ КОМПЬЮТЕРНОЙ ТОМОГРАФИИ ДЛЯ ОЦЕНКИ ПАТОЛОГИИ ВЕРХНИХ ДЫХАТЕЛЬНЫХ ПУТЕЙ У ПАЦИЕНТОВ С ЗАБОЛЕВАНИЯМИ ЗУБОЧЕЛЮСТНОЙ СИСТЕМЫ}

\footnotetext{
Аннотация. С применением конусно-лучевой компьютерной томографии (КЛКТ) изучены показатели состояния верхних дыхательных путей пациентов с заболеваниями зубочелюстной системы и синдромом обструктивного апноэ сна.

Пациенты были разделены на три группы. Контрольная группа (группа 1) включала в себя данные КЛКТ, полученные от 33 здоровых пациентов, группа 2 - данные КЛКТ, полученные от 136 пациентов с заболеваниями зубочелюстной системы (частичной вторичной адентией в сочетании с хроническим генерализованным периодонтитом) без признаков расстройств сна, группа 3 - данные КЛКТ, полученные от 70 пациентов с частичной вторичной адентией в сочетании с глубоким дистальным прикусом и синдромом обструктивного апноэ сна.

Метод КЛКТ с использованием предложенных диагностических критериев позволяет выявить не только стоматологические заболевания, но и нарушения в функционировании верхних дыхательных путей, в частности причины возникновения апноэ сна. Снижение показателей диагностических критериев верхних дыхательных путей на 40 \% и более по сравнению с нормативными показателями здоровых пациентов достоверно значимо приводит к нарушениям нормального функционирования дыхательных путей и развитию апноэ. Глубокий дистальный прикус и вторичная адентия обусловливают наличие вогнутой конфигурацией верхних дыхательных путей и расположение минимальной площади поперечного сечения ниже окклюзионной плоскости, что достоверно повышает вероятность развития и прогрессирования синдрома обструктивного апноэ сна.
} 
Ключевые слова: апноэ сна, конусно-лучевая компьютерная томография, периодонтит, адентия, верхние дыхательные пути

Для цитирования: Перспективы применения конусно-лучевой компьютерной томографии для оценки патологии верхних дыхательных путей у пациентов с заболеваниями зубочелюстной системы / С. П. Рубникович [и др.] // Вес. Нац. акад. навук Беларусі. Сер. мед. навук. - 2020. - Т. 17, № 3. - С. 346-352 (in English). https://doi.org/10.29235/18146023-2020-17-3-346-352

Introduction. The problem of interdisciplinary relationship between dental and otorhinolaryngology problems is very urgent due to insufficient scientific justification of the methods used for their diagnosis and treatment. Hence, studies of these problems are of high medico-social and economic significance [1-4].

Cone beam computed tomography (CBCT) has become widely used in medicine in the recent time, which significantly increased the capacity for X-ray research. This is a contemporary tomography procedure, allowing minimum irradiation and obtaining maximum information. The cone beam tomography is the best method for investigation of different dentition system diseases, because it enables 3D modelling of the jaw. Many useful CBCT algorithms have been developed. For example, researches are performed to identify not only dentition system pathologies, but also the risks of dysfunction of the upper respiratory tract (URT). Analysis of the reference sources has demonstrated that diagnostic investigations of the upper respiratory tract condition in patients with dentition system diseases using the CBCT indicators present a substantial scientific and practical interest for medical specialists and are very important for the researchers [5-8].

High frequency of dental disorders leads to premature loss of teeth and morphological changes in the dentition structure, resulting not only in functional dentition disorders, but also in structural pathologies of the oropharynx region, in particular, causing its misconfiguration [9-11].

3D imaging is a highly efficient method for visualization and identification of the configuration, inter alia, the diffusion-induced narrowing (narrowing of a clearance that is greater in length) or local narrowing of the respiratory tract. Reducing the radius of the airways increases the resistance of the airways, whereas greater inhalation efforts are needed to maintain the airflow. Increased inhalation efforts tend to boost the differential pressure between the mouth cavity and the alveoli, which results in apnoea. Currently, dentists can perform screening of patients with dentition and facial diseases in order to identify dysfunctions of the upper respiratory tract based on CBCT data [12-20].

The goal of the study was to analyse the upper respiratory tract condition indicators, obtained by means of CBCT in patients with dentition system diseases and the obstructive sleep apnoea syndrome.

Materials and methods of study. The study was performed at the Chair of Prosthetic Dentistry and Orthodontics with a Course of Paediatric Dentistry of the Belarusian Medical Academy of Postgraduate Education.

The following requirements were specified in order to use CBCT data in the study. Patients aged 45-55 years who had partial edentia and a deep distal occlusion and were diagnosed as having generalized chronic periodontitis and the obstructive sleep apnoea syndrome were selected for the study.

The patients were divided into 3 study groups.

The control group (the 1st study group) included CBCT data obtained from 33 healthy patients without dentition system diseases, who visited dentists for prevention purposes.

The 2nd study group included CBCT data obtained from 136 patients with dentition system diseases (partial secondary edentia combined with generalized chronic periodontitis) without signs of sleep disorders.

The 3rd study group included CBCT data obtained from 70 patients with partial secondary edentia combined a deep distal occlusion and the obstructive sleep apnoea syndrome, confirmed by a home sleep test (HST).

All groups were comparable by age ( $p=0.084-0.092)$ and $\operatorname{sex}\left(\chi^{2}=0.33-0.64, p=0.098-0.112\right)$.

The diagnostic criteria for the upper respiratory tract were investigated, such as:

the total volume of the respiratory tract in the oropharynx region;

the cross-sectional area of the oropharynx region;

the minimum cross-sectional area; 
the anteroposterior and lateral dimensions of the minimum cross-sectional area;

the localization of the minimum cross-sectional area in the upper and lower oropharynx regions;

the configuration: 3D reconstruction of the investigated respiratory tract (elliptical, square, concave, or perforated).

The study did not include patients who had: total edentia (the position of the tongue may change after removal of the denture from the mouth); malocclusion (including mandibular retrognathia and prognathism); cardiovascular diseases, including previously reported myocardial infarction or angina pectoris; renal diseases; lung problems; previous stroke; anxiety/panic disorders; neurological disorders, such as epilepsy or narcolepsy; restless legs syndrome; drug abuse/addiction; diabetes mellitus; liver disease; alcoholism or excessive use of caffeine-containing drinks and tobacco products.

The patients were scanned by means of cone beam computed tomography in the upright position with the natural head posture, using a cephalostat. Cone beam computed tomography was performed by means of ProMax 3D Mid (Planmeca, Finland), applying a conical X-ray beam with high resolution.

The findings were statistically processed using the statistical analysis package Statistica for Windows 10.0 (StatSoft Inc., Talca, USA).

The distribution was assessed according to the Shapiro-Wilk test of normality. All variables had normal distribution. The differences between the groups were evaluated on the basis of Student's $t$-test; the qualitative data were compared using Pearson's $\chi^{2}$ criterion; the differences between the groups by the frequency of the studied sign were determined on the basis of Fisher's ratio test; and the multiple factor dispersion analysis was used to identify the dependence. The boundary statistical significance level was taken at $p<0.05$.

Results and discussions. The studies helped identify dynamic changes of the total volume of the respiratory tract in the patients from the study groups (Tab. 1). Authentic changes of the total volume of the respiratory tract in relation to the control group of patients were noted in the 1st and 2nd study groups. Thus, it was found that the total volume of the respiratory tract was reduced by $15.16 \%(p<0.01)$ in patients from the 2nd study group and by $59.16 \%$ in patients from the 3rd study group $(p<0.001)$. Changes were found in the cross-sectional area of the upper respiratory tract. In the 2nd study group, this indicator was reduced definitely by $15.32 \%(p<0.01)$, and in the 3 rd study group by $45.86 \%$ $(p<0.001)$, as compared to the control group (Tab. 2).

$\mathrm{T} a \mathrm{~b} 1 \mathrm{e}$ 1. The upper respiratory tract parameters in the patients from the control group (1) and the study groups $(2,3)$ according to $\mathrm{CBCT}$ data

\begin{tabular}{|l|c|c|c|}
\hline \multicolumn{1}{|c|}{ Parameter } & Group & $\mathrm{M} \pm \mathrm{SE}$ & $p$ \\
\hline \multirow{4}{*}{ Total volume of the respiratory tract, $\mathrm{cm}^{3}$} & 1 & $14.25 \pm 0.76$ & $<0.01$ \\
\cline { 2 - 4 } & 2 & $12.09 \pm 0.27^{*}$ & $<0.001$ \\
\cline { 2 - 4 } & 3 & $5.82 \pm 0.17^{* *}$ & $<0.01$ \\
\hline \multirow{3}{*}{ Cross-sectional area, mm ${ }^{2}$} & 1 & $2617.71 \pm 73.55$ & $<0.001$ \\
\cline { 2 - 4 } & 2 & $2216.18 \pm 37.94^{*}$ & $<0.01$ \\
\cline { 2 - 4 } Minimum cross-sectional area (MCSA), mm ${ }^{2}$ & 3 & $1417.34 \pm 38.15^{* *}$ & $<0.001$ \\
\hline \multirow{3}{*}{ Anteroposterior dimension of MCSA, mm } & 1 & $296.45 \pm 3.21$ & $<0.01$ \\
\cline { 2 - 4 } & 2 & $215.78 \pm 6.73^{*}$ & $<0.001$ \\
\hline \multirow{3}{*}{ Lateral dimension of MCSA, mm } & 3 & $162.76 \pm 7.21^{* *}$ & $<0.01$ \\
\cline { 2 - 4 } & 2 & $8.40 \pm 0.16^{*}$ & $<0.01$ \\
\hline
\end{tabular}

N o t e. * - the indictors have a truly significant difference from the indicators in the control group $(<0.01), * *$ the indictors have a truly significant difference from the indicators in the control group $(<0.001)$. 
Ta b le 2. CBCT data on the minimum cross-sectional area localization in the oropharynx region of the study and the control group patients

\begin{tabular}{|l|c|c|}
\hline \multirow{2}{*}{\multicolumn{1}{|c|}{ Patient group }} & \multicolumn{2}{|c|}{ MCSA localization in the oropharynx region, \%* } \\
\cline { 2 - 3 } & upper & lower \\
\hline 1st control group & 51.5 & 48.5 \\
\hline 2nd study group & 41 & 59 \\
\hline 3rd study group & 20 & 80 \\
\hline
\end{tabular}

N o t e. Data were calculated based on the premise that the number of patients in each group was taken as $100 \%$.

The minimum cross-sectional area of the airways in the 2nd and 3rd study groups was found with certainty to be smaller than in the control group by $19.92 \%(p<0.01)$ and $45.09 \%(p<0.001)$, respectively. Also, it was found that the anteroposterior and lateral dimensions of the minimum crosssectional area of the respiratory tract were reduced in the patients from the 2nd group by 19.23 and $23.98 \%(p<0.01)$, respectively, and in the patients from the 3rd study group by 64.50 and $41.32 \%$ $(p<0.001)$, respectively, as compared to the same indicators in the control group.

Analysis of the CBCT data for the patients with dentition system diseases (partial secondary edentia combined with chronic generalized periodontitis, as well as partial secondary edentia combined with deep distal occlusion and the obstructive sleep apnoea syndrome) identified disorders of the upper respiratory tract. The most significant reduction of the total volume of the respiratory tract, the crosssectional area and the minimum cross-sectional area (by more than $40 \%, p<0.001$ ) was identified in patients who previously had dentition system diseases combined with deep distal occlusion and the obstructive sleep apnoea syndrome.

Analysis of the factors that have the most significant adverse effect on the upper respiratory tract condition demonstrated that the presence of a deep distal occlusion resulted in a concave configuration of the URT and the localization of the minimum cross-sectional area below the occlusion plane in the lower region of the oropharynx, which significantly increased the probability of development and progression of the obstructive sleep apnoea syndrome $(\mathrm{F}=7.67-7.51$, $p=0.019-0.025)$ (Fig. 1-3).

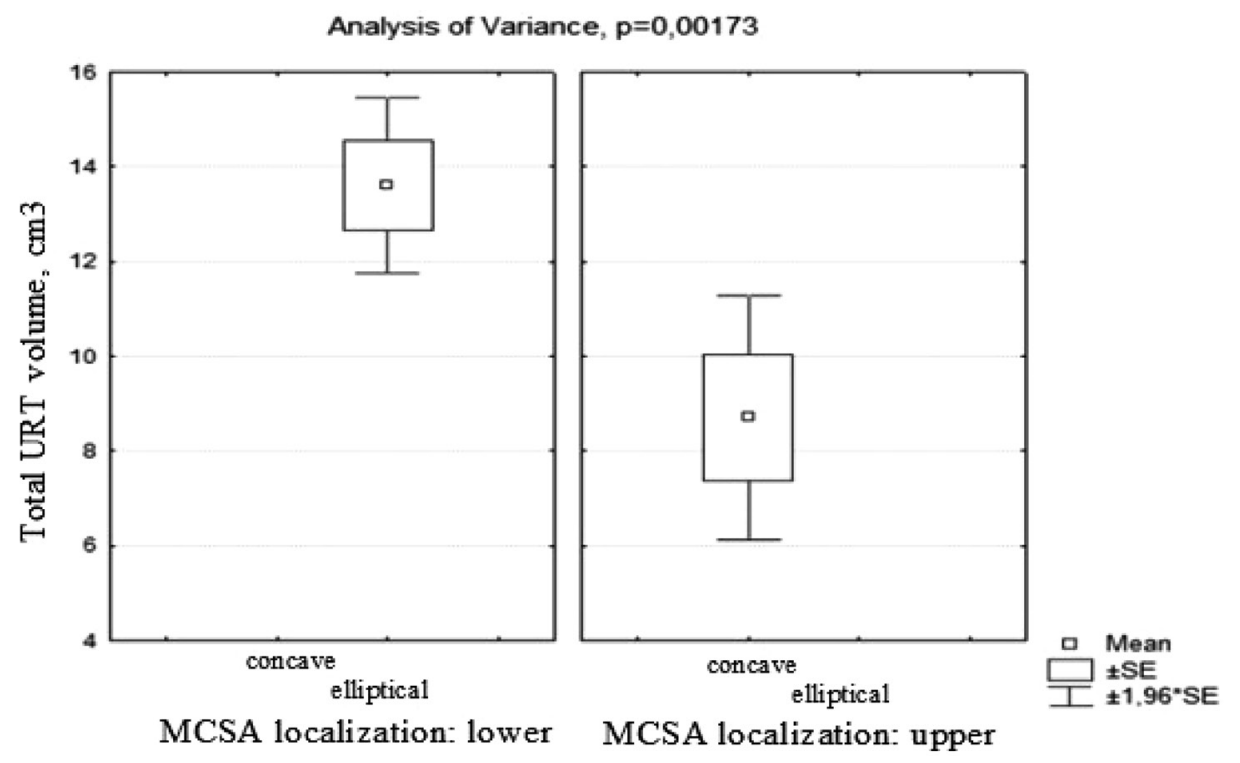

Fig. 1. The predictors corresponding to the highest probability of OSAS development 


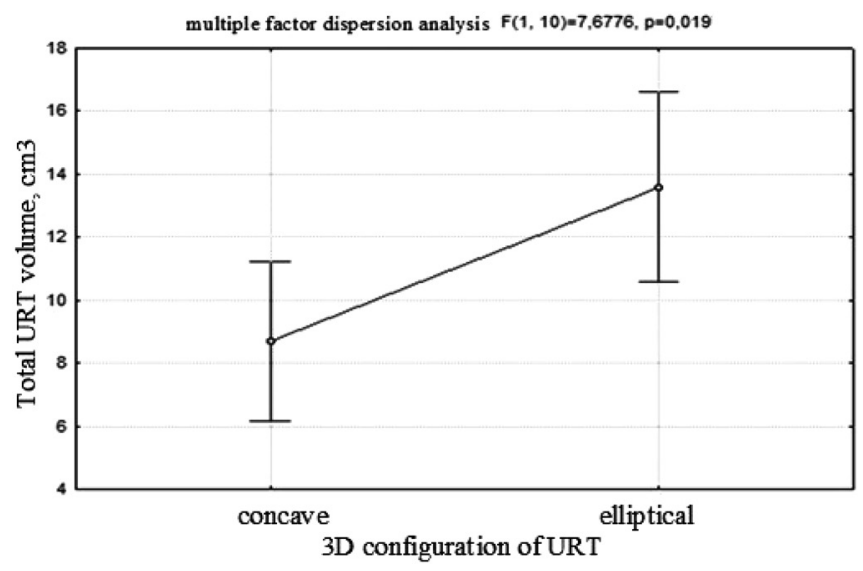

Fig. 2. The effect of the upper respiratory tract configuration on its total volume

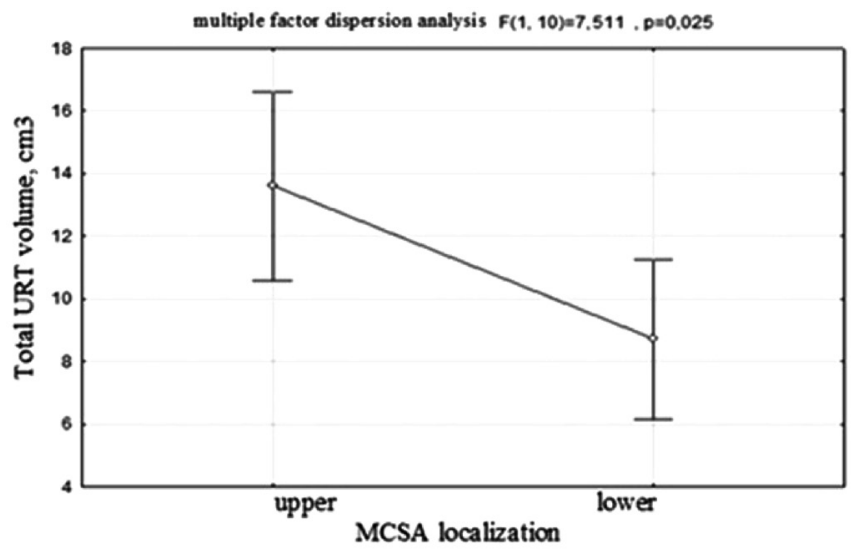

Fig. 3. The effect of the minimum cross-sectional area localization in the oropharynx lower region on the total upper respiratory tract volume

\section{Conclusions}

1. The CBCT method using the proposed diagnosis criteria made it possible to identify not only dentition system diseases, but also dysfunction of the upper respiratory tract, in particular, the causes of OSAS development.

2. It was found with confidence that the reduction of the indicators of URT diagnostic criteria by $40 \%$ or more $(p<0.01-0.001)$, as compared to the regulatory indicators of healthy patients, led to dysfunction of the respiratory tract and development of apnoea.

3. Deep distal occlusion and secondary edentia conditioned the presence of the URT concave configuration and the minimum cross-sectional area localization below the occlusion plane, which increased with certainty the probability of development and progression of the obstructive sleep apnoea syndrome $(\mathrm{F}=7.67, p=0.019-0.025)$.

Conflict of interests. The authors declared no conflict of interests.

\section{References}

1. Kolyadich Zh. V., Kalinkin A. L. Obstructive sleep apnea syndrome: a view of an otorhinolaryngologist and sleep specialist. Terapiya [Therapy], 2016, no. 1, pp. 42-50 (in Russian).

2. Zatoloka D. A., Furmanchuk D. A., Kolyadich Zh. V., Tishkevich E. S., Andrianova T. D., Frolov Yu. Yu., MakarinKibak A. S. The modern approaches to diagnostics of obstructive sleep apnoea syndrome. Vestnik otorinolaringologii [Bulletin of otorhinolaryngology], 2013, no. 1, pp. 58-60 (in Russian).

3. Holty J.-E., Guilleminault C. Maxillomandibular advancement for the treatment of obstructive sleep apnea: a systematic review and meta-analysis. Sleep Medicine Reviews, 2010, vol. 14, no. 5, pp. 287-297. https://doi.org/10.1016/j.smrv.2009.11.003 
4. Susarla S. M., Thomas R. J., Abramson Z. R., Kaban L. B. Biomechanics of the upper airway: changing concepts in the pathogenesis of obstructive sleep apnea. International Journal of Oral and Maxillofacial Surgery, 2010, vol. 39, no. 12, pp. 1149-1159. https://doi.org/10.1016/j.ijom.2010.09.007

5. Schwab R. J., Pasirstein M., Pierson R., Mackley A., Hachadoorian R., Arens R., Maislin G., Pack A. I. Identification of upper airway anatomic risk factors for obstructive sleep apnea with volumetric magnetic resonance imaging. American Journal of Respiratory and Critical Care Medicine, 2003, vol. 168, no. 5, pp. 522-530. https://doi.org/10.1164/rccm.200208-866oc

6. Park J. G., Ramar K., Olson E. J. Updates on definition, consequences, and management of obstructive sleep apnea. Mayo Clinic Proceedings, 2011, vol. 86, no. 6, pp. 549-555. https://doi.org/10.4065/mcp.2010.0810

7. Enciso R., Nguyen M., Shigeta Y., Ogawa T., Clark G. T. Comparison of cone-beam CT parameters and sleep questionnaires in sleep apnea patients and control subjects. Oral Surgery, Oral Medicine, Oral Pathology, Oral Radiology, and Endodontics, 2010, vol. 109, no. 2, pp. 285-293. https://doi.org/10.1016/j.tripleo.2009.09.033

8. Alsufyani N. A., Al-Saleh M. A., Major P. W. CBCT assessment of upper airway changes and treatment outcomes of obstructive sleep apnoea: a systematic review. Sleep Breath, 2013, vol. 17, pp. 911-923.

9. Rubnikovich S. P., Denisova Y. L., Vladimirskaya T. E., Andreyeva V. A., Kvacheva Z. B., Panasenkova G. Y., Volotovsky I. D. Regenerative cell technologies for gingival recession treatment. Modern technologies in medicine, 2018, vol. 10, no. 4, pp. 94-104. https://doi.org/10.17691/stm2018.10.4.11

10. Rubnikovich S. P., Khomich I. S. Denisova Yu. L. Morphological changes in bone tissue around dental implants after low-intensity ultrasound applications. Vestsi Natsyyanal'nai akademii navuk Belarusi. Seriya meditsinskikh navuk = Proceedings of the National Academy of Sciences of Belarus. Medical series, 2020, vol. 17, no. 1, pp. $20-27$ (in Russian).

11. Rubnikovich S. P., Maizet A. I., Denisova Yu. L., Kopylova I. A., Avanesyan R. A. The effect of magnetophototherapy on morphological changes of tissues of pathologically changed periodontium. Meditsinskii vestnik Severnogo Kavkaza= Medical news of North Caucasus, 2017, vol. 12, no. 3, pp. 303-307. https://doi.org/10.14300/mnnc.2017.12095

12. Fomin N. A., Rubnikovich S. P., Bazylev N. B. New possibilities of investigating blood flow in soft tissues of the mouth. Journal of Engineering Physics and Thermophysics, 2008, vol. 81, no. 3, pp. 533-543. https://doi.org/10.1007/s10891008-0065-9

13. Sirak S. V., Rubnikovich S. P., Shchetinin E. V., Perikova M. G., Petrosyan G. G., Bykova N. I., Kobylkina T. L., Didenko M. O. Immunohistochemical evaluation of changes in periodontal tissues in experimental animals with bone skeleton osteoporosis. Meditsinskii vestnik Severnogo Kavkaza = Medical news of North Caucasus, 2019, vol. 14, no. 4, pp. 681-685 (in Russian). https://doi.org/10.14300/mnnc.2019.14168

14. Shchetinin E. V., Sirak S. V., Rubnikovich S. P., Kochkarova Z. M., Andreev A. A., Muratova A. Yu., Perikova M. G., Petrosyan G. G. Morphometric parameters of reparative regeneration of the bone tissue in terms of medicinal phonophoresis with hydrocortisone and hyaluronic acid. Meditsinskii vestnik Severnogo Kavkaza = Medical news of North Caucasus, 2019, vol. 14, no. 4, pp. 660-663 (in Russian). https://doi.org/10.14300/mnnc.2019.14163

15. Garunov M. M., Sevbitov A. V., Dolgalev A. A., Sirak S. V., Solovyeva O. A., Remizova A. A., Dzgoeva M. G., Rubnikovich S. P. Clinical and radiographic assessment of osteointegration of dental implants after remodeling of the perimplant zone. Meditsinskii vestnik Severnogo Kavkaza = Medical news of North Caucasus, 2019, vol. 14, no. 4, pp. 699-701 (in Russian). https://doi.org/10.14300/mnnc.2019.14174

16. Rubnikovich, S. P., Denisova, Y. L., Fomin, N. A. Digital laser speckle technologies in measuring blood flow in biotissues and the stressed-strained state of the maxillodental system. Journal of Engineering Physics and Thermophysics, 2017, vol. 90. no. 6, pp. 1513-1523. https://doi.org/10.1007/s10891-017-1713-8

17. Denisova Y. L., Bazylev N. B., Rubnikovich S. P., Fomin N. A. Laser speckle technology in stomatology. diagnostics of stresses and strains of hard biotissues and orthodontic and orthopedic structures. Journal of Engineering Physics and Thermophysics, 2013, vol. 86, no. 4, pp. 940-951. https://doi.org/10.1007/s10891-013-0915-y

18. Bazylev N. B., Rubnikovich S. P. Investigation of the stressed-strained state of cermet dentures using digital laser speckle-photographic analysis. Journal of Engineering Physics and Thermophysics, 2009, vol. 82, no. 4, pp. 789-793. https:// doi.org/10.1007/s10891-009-0247-0

19. Fomin N., Fuentes C., Hirano T., Rubnikovich S., Bazylev N., Lavinskaya E. [et al.]. Laser monitor for soft and hard biotissue analysis using dynamic speckle photography. Journal of Laser Physics, 2003, vol. 13, no. 5, pp. 786-795.

20. Ogawa T., Enciso R., Shintaku W. H., Clark G. T. Evaluation of cross-section airway configuration of obstructive sleep apnea. Oral Surgery, Oral Medicine, Oral Pathology, Oral Radiology, and Endodontics, 2007, vol. 103, no. 1, pp. $102-108$. https://doi.org/10.1016/j.tripleo.2006.06.008

\section{Information about the authors}

Sergey P. Rubnikovich - D. Sc. (Med.), Professor, Head of the Department. Belarusian Medical Academy of Postgraduate Education (3/3, P. Brovka Str., 220013, Minsk, Republic of Belarus). E-mail: rubnikovichs@mail.ru

Irina S. Abelskaya - D. Sc. (Med.), Professor. Belarusian Medical Academy of Postgraduate Education (3/3, P. Brovka Str., 220013, Minsk, Republic of Belarus). E-mail: abelskaya. irina@gmail.com

\section{Информация об авторах}

Рубникович Сергей Петрович - д-р мед. наук, профессор, заведующий кафедрой. Белорусская медицинская академия последипломного образования (ул. П. Бровки, 3/3, 220013, г. Минск, Республика Беларусь). E-mail: rubnikovich@, mail.ru

Абельская Ирина Степановна - д-р мед. наук, профессор. Белорусская медицинская академия последипломного образования (ул. П. Бровки, 3/3, 220013, г. Минск, Республика Беларусь). E-mail: abelskaya.irina@gmail.com 
Yuliya L. Denisova - D. Sc. (Med.), Professor. Belarusian State Medical University (83, Dzerzhynskii Ave., 220116, Minsk, Republic of Belarus). E-mail: denisova-yul@mail.ru

Sergey V. Sirak - D. Sc. (Med.), Professor, Head of the Department. Stavropol State Medical University (310, Mir Str., 355017, Stavropol, Russian Federation). E-mail: sergejsirak@, yandex.ru

Vladimir G. Shishov - Researcher. Belarusian Medical Academy of Postgraduate Education (3/3, P. Brovka Str., 220013, Minsk, Republic of Belarus). E-mail: vladimir shishov@inbox.ru
Денисова Юлия Леонидовна - д-р мед. наук, професcop. Белорусский государственный медицинский университет (пр. Дзержинского, 83, 220116, г. Минск, Республика Беларусь).

Сирак Сергей Владимирович - д-р мед. наук, профессор, заведующий кафедрой. Ставропольский государственный медицинский университет). E-mail: sergejsirak@ yandex.ru mailto:rubnikovich@mail.ru

Шишов Владимир Григорьевич - науч. сотрудник. Белорусская медицинская академия последипломного образования (ул. П. Бровки, 3/3, 220013, г. Минск, Республика Беларусь). E-mail: vladimir_shishov@inbox.ru 